\title{
Skal den offentlige sektor være innovativ?
}

\section{Indledning}

Den offentlige sektor udgøres af en række demokratisk styrede og politiske institutioner, der er offentlige, fordi de beskæftiger sig med almene anliggender for samfundets borgere. Den demokratiske samtale og den politiske offentlighed er ikke del af den offentlige sektor som sådan, men leverer input til dens politiske styring (Habermas 1996). Den politiske viljes- og meningsdannelse er således væsentlig for selve bestemmelsen af de almene anliggender, som det offentlige beskæftiger sig med. Netop fordi den offentlige sektor er politisk, demokratisk styret og typisk betragtes som adskilt fra markedet og privatsfæren, er det bemærkelsesværdigt, at et begreb som 'innovation' nu er dukket op som et centralt begreb i politiske strategier for den offentlige sektor og i forskning om offentlig styring. Både fra politisk og forskningsmæssig side er der inden for de senere år kommet et intenst fokus på innovation i den offentlige sektor, og dette har forplantet sig til de offentlige organisationer. I en survey-undersøgelse foretaget af forskere på Roskilde Universitet svarer 46 procent af de adspurgte offentlige ledere, at innovation i høj eller meget høj grad er del af deres organisations vision og strategiplan, og 61 procent af lederne har desuden gennemført innovationsprojekter inden for de sidste tre år (Sørensen og Torfing 2012: 25).

Da innovation er et ord med meget positive konnotationer, lyder det måske umiddelbart rigtig godt, at den offentlige sektor skal være mere innovativ. Men det er ikke altid lige klart, hvad det nærmere bestemt betyder, eller hvad det betyder for den offentlige sektor, når et sådant begreb om udvikling bliver styrende. Den økonomiske og erhvervsøkonomiske teoris begreb om innovation har nemlig stort set enerådende opnået definitionsmagt over begrebet. Og dette er selvom innovation etymologisk og historisk set ikke 
nødvendigvis er et økonomisk begreb, da flere discipliner har taget begrebet til sig, blandt andet sociologi og antropologi (Robertson 1967: 14; Godin 2008: 24; Paulsen 2012; Klausen 2012). Innovation kan referere til social forandring i mere bred forstad (Godin 2012) og hos sociologen Everett Rogers (1995) anvendes begrebet eksempelvis bredt til at betegne nye idéer, praksisser eller genstande. Hos Rogers er det afgørende, at en innovation indebærer en nyhedsværdi i den kontekst, hvor den indoptages, altså for det individ eller organisation, der adopterer innovationen (Rogers 1995: 11). Rogers ser på udbredelsen af innovationer og på hvordan nye idéer og teknologier spreder sig i samfundet og i forskellige kulturer (Rogers 1995). Endvidere er der inden for de senere år opstået en gren af forskningen, der beskæftiger sig eksplicit med social innovation forstået således, at fokus er på skabelse af social, snarere end økonomisk, værdi (Austin et al. 2006; Dees 1998).

Ikke desto mindre er det det økonomiske innovationsbegreb, som har haft størst indflydelse på definitioner af innovation i den offentlige sektor, både inden for forskningen og i de danske politiske innovationsstrategier. I den forstand er det økonomiske begreb blevet dominerende, selvom innovation i princippet kan forstås på flere forskellige måder. Det er dette forhold, der danner baggrund for artiklens problemstilling. Hos Joseph Schumpeter, der betragtes som innovationsteoriens grundlægger, og som har afgørende indflydelse på også nyere innovationsteori, er innovation et begreb, der forklarer økonomisk udvikling (Lundvall 2007). Det henviser til udviklingen af nye produkter, processer, markedsføringsmetoder og åbningen af nye markeder, som fører til spring i den økonomiske udvikling. De virksomheder eller iværksættere, der introducerer disse innovationer til markedet, vil for en tid have konkurrencefordele og opnå en høj profit. Innovation udvikles her med henblik på at skabe konkurrencemæssige fordele (Klausen 2012: 241), og adskiller sig fra blot forandring eller udvikling ved at det gør en økonomisk forskel (Drejer 2004). På grund af antagelsen om sammenhæng mellem innovationskraft og konkurrencedygtighed er innovationsforskningens hovedinteresse at afdække barrierer og fremmende faktorer for innovation og at finde ud af, hvordan innovation ledes (Fagerberg 2007; Tidd, Bessant and Pavitt 2001). Med dette fokus på betingelserne for innovation, kombineret med en 
uimodsagt antagelse om, at innovation er noget positivt, ender innovationsteorien med at negligere en diskussion og refleksion over selve innovationsbegrebet (Langergaard 2011). Og dette synes at gå igen i forhold til anvendelsen af begrebet i en offentlig kontekst.

Derved er der en risiko for, at innovation i den offentlige sektor bliver ureflekteret formet $\mathrm{i}$ den økonomiske innovationsteoris billede. Eksempelvis ses dette ved, at interessen for barrierer og fremmende faktorer overtages af store dele af forskningen $\mathrm{i}$ innovation i den offentlige sektor (Altschuler and Zegans 1990; Becheikh et al. 2007; Borins 2006; Christopher 2003; Golden 1990; Libbey 1994; Sanger and Levin 1992), herunder det danske CLIPS projekt (RUC, 2013). Store dele af forskningen i offentlig innovation, fremstår derved ikke tilstrækkeligt reflekteret hvad angår selve innovationsbegrebet. Samtidig foregår en del aktivitet for at fremme innovation, selvom det ikke er klart, hvad det gør ved den offentlige sektor. Derfor er der god grund til en diskussion om, hvorvidt innovation er et passende udviklingsbegreb, når vi tager de demokratiske aspekter ved den offentlige sektor $i$ betragtning. Jeg vil stille spørgsmålet: bør den offentlige sektor overhovedet være innovativ?

I artiklen gennemføres en diskussion af begrænsningerne ved at tænkte innovation inden for rammerne af den økonomiske innovationsteori i den offentlige sektors demokratiske og politiske kontekst. Det er derved ikke et spørgsmål om, hvorvidt forandringer i de offentlige institutioner bør være radikale, revolutionære eller blotte gradvise reformer, eller om der i bestemte henseender ikke skal være plads til innovation forstået som forandring i mere bred forstand. Spørgsmålet går snarere på, hvad de bestemte gældende forståelser af innovation gør for den offentlige sektor som politisk demokratisk institution. Argumentet går på at tydeliggøre, hvilke aspekter ved den offentlige sektor, der bør have en fremtrædende plads $i$ et offentligt innovationsbegreb, og hvordan vi kan tænke den offentlige sektors demokratiske forankring ind i et offentligt innovationsbegreb. Hvis innovation forstås $\mathrm{i}$ den private sektors billede, er det ikke givet, at den offentlige sektor bør være innovativ.

For at kunne besvare spørgsmålet vil jeg diskutere, hvad det implicerer for den offentlige sektors demokratiske dimensioner, når innovation bliver et styrende begreb for dens udvikling. Altså spørgsmålet om: Hvad gør innovation som udviklingsbegreb ved 
det særligt offentlige ved den offentlige sektor? Det handler om betingelserne for en demokratisk offentlig sektor i lyset af introduktionen af innovation i den offentlige sektor. Først vil jeg indkredse de offentlige og demokratiske dimensioner ved den offentlige sektor med tænkere som Jürgen Habermas, Nancy Fraser og Hannah Arendt. Dernæst skal jeg præsentere idéen om, at den offentlige sektor skal være innovativ, herunder hvor vi ser idéen $i$ en dansk kontekst. Derefter kommer artiklens diskussion af forskellige aspekter af innovationsbegrebets forhold til de offentlige, demokratiske dimensioner ved den offentlige sektor. Artiklens diskussion er en normativ, politisk filosofisk diskussion, som tager udgangspunkt $\mathrm{i}$ et deliberativt demokratiideal. Endelig konkluderer jeg, at vi må gentænke innovationsbegrebet, hvis vi vil være sikre på, at det skal understøtte den offentlige sektors offentlige og demokratiske dimensioner.

\section{Demokrati og offentlighed}

Spørgsmålet er, om et begreb, der hidtil mest har handlet om udviklingen af konkurrencedygtige virksomheder, kan overføres til vores offentlige, demokratiske institutioner? I den forbindelse er distinktionen mellem det offentlige og det private relevant. Distinktionen er dog flertydig (se eksempelvis Geuss 2001) og ligeledes stærk omdiskuteret (Young 1990; Fraser 1985). Ikke desto mindre har vi brug for et begreb om offentlighed for at kunne bestemme de normative konstitutionsbetingelser for den offentlige sektor, og derved diskutere innovation i forhold til det offentlige.

En gængs måde at skelne er ved at sige, at det offentlige henviser til det politiske og fælles, mens det private henviser til privatsfæren i form af husholdningen/familien, eller til markedet (økonomien), som typisk benævnes den private sektor. Disse to betydninger af privat er forbundne gennem det græske ord for husholdning oikos, som udgør det etymologiske grundlag for ordet økonomi (Arendt 2007: 55). I forhold til den offentlige sektor kan man desuden betegne de offentlige anliggender, som den offentlige sektor varetager, som demokratisk legitimerede og som noget, der betragtes som grundlæggende for borgerne for at leve et godt liv i samfundet. Det er knyttet til et spørgsmål om retfærdighed og borgeres rettigheder 
og derfor forskellige fra de ydelser, der udbydes på markedet og som afhænger af den enkeltes betalingsevne (Eriksen 1999).

Når det er sagt, kan det offentlige også forstås på flere måder, nemlig dels som den offentlige sfære for politisk debat, deliberation og offentlig meningsdannelse, dels som det formelle administrative statssystem (Fraser 1985). I den forbindelse er netop sammenhængen mellem de to begreber om det offentlige central. De almene og politiske anliggender, som den offentlige sektor er ansvarlig for, bliver netop almengjort ved at være genstand for meningsdannelse i den demokratiske offentlighed. I Habermas' deliberative demokratimodel spiller den offentlige deliberation og meningsdannelse en væsentlig rolle i den offentlige menings normative gyldighed, idet argumentationen og den intersubjektive praktiske fornuft (sikret gennem diskursreglerne) giver de bedre argumenter gode betingelser for konsensus (Habermas 1996: 278-279). Det er på den måde, at de anliggender der betragtes som almene i offentligheden kan siges at være retfærdiggjort som netop almene anliggender. Men disse offentlige og almene anliggender, som er genstand for den offentlige menings- og viljesdannelse i den offentlige sfære, må tages op af det politiske system, for at man kan handle på dem og de kan blive genstand for problemløsning (Habermas 1996: 359-360). Det er her, den offentlige sektor og de politiske institutioner kommer ind som en institutionalisering af de offentlige anliggender.

Men hvad, der er alment og dermed offentligt, er ikke en statisk størrelse. Ligeledes er der også flere måder, hvorpå man kan trække grænsen mellem offentligt og privat. Forvaltningslitteraturen giver forskellige bud på denne distinktion, som på sin vis lægger sig op ad den ovenfor nævnte. Barry Bozeman (1987) forstår eksempelvis distinktionen ud fra en skalamodel, hvor offentlighed bliver et gradsspørgsmål, således at en organisation er offentlig i større eller mindre udstrækning, alt efter i hvilken grad den er underlagt politisk autoritet (Bozeman 1987: xi). Denne distinktion baserer sig på overvejende empiriske forskelle, snarere end på normative eller begrebslige forskellige, der henviser til normative konstitutionsbetingelser for henholdsvis offentlige og private organisationer. Den rummer derved ikke samme normative forståelse af det offentlige som almengjort, som vi ser hos Habermas. Implikationen af denne form for sondring er, at alle organisationer i en eller anden forstand 
er offentlige. Grænsen bliver et kontinuum, således at disse modeller er velegnede til at forholde sig til de organisationer, der befinder sig i gråzonen mellem offentlig og privat sektor. Sådanne sondringer har dog en begrænsning i forhold til at indgå i filosofisk normative diskussioner af værdier og normer knyttet til forskellige typer af organisationer og derved til at diskutere om det giver mening at sondre mellem offentligt og privat ud over i empirisk forstand.

Man kan se det som et politisk spørgsmål i sig selv, hvordan grænsen mellem det offentlige og private skal trækkes. Denne diskussion har en central plads i dele af den feministiske tænkning. Hvis man trækker en distinktion, som om det offentlige og private var essentielt, eller naturligt, forskellige (en natural kinds distinktion) kan den potentielt blive ideologisk, da den kan legitimere at man holder bestemte anliggender uden for politisk debat, som man tidligere har set med revselse af børn og vold mod kvinder i hjemmet (se Fraser 1985: 100). Men man kan opretholde en procedural snarere end en substantiel sondring, hvor bestemmelsen af hvilke anliggender, der er offentlige og private ligeledes afhænger af deliberation og argumentation i offentligheden. De offentlige anliggender gør krav på en form for almenhed og retfærdighed, men det er deltagerne selv, der afgør, hvilke konkrete anliggender, der er private og hvilke der er offentlige (Habermas 1996; Fraser 1992; Benhabib 1992). Det er centralt, at de offentlige anliggender ikke er statiske og kan bestemmes én gang for alle. De er derimod afhængige af vedvarende at være genstand for diskussion i den politiske offentlighed. Derfor er den offentlige sektors legitimitet til stadighed bundet op på denne offentlighed og på de anliggender, der betragtes som almene og politiske.

Ligeledes er det også et politisk og dermed demokratisk anliggende, hvordan den offentlige sektor løser sine opgaver - overordnet set naturligvis, da der også er dele af den offentlige drift, som kan siges at være af mere teknisk karakter. Det gælder dog ikke de offentlige services til eksempel, hvor mødet med borgeren er grundlæggende for hvordan rettigheder aktualiseres. De services, som den offentlige sektor udbyder er offentlige og almene, dvs. betragtes som væsentlige betingelser for det gode liv eller det retfærdige samfund, som ideelt set hænger sammen med, at de er demokratisk legitimeret (Eriksen 1999). Således er den offentlige sektors 
normative konstitutionsbetingelser radikalt forskellige fra den private sektors, hvilket også må afspejle sig i et begreb om innovation. Vi skal nu se nærmere på og diskutere, hvordan innovation som forandringsbegreb understøtter en udvikling af den offentlige sektors offentlige og demokratiske dimensioner.

\section{Innovation som begreb for udviklingen af den offentlige sektor}

Idéen om, at den offentlige sektor skal være innovativ går i international sammenhæng et par årtier tilbage (Borins 2006; Grady 1992; Becheikh et al. 2007). Interessen for en innovativ offentlig sektor hænger sammen med de forskellige moderniseringsprogrammer, som har præget OECD landene i de seneste årtier og med New Public Management-bølgen mere generelt (Ejersbo og Greve 2005: 13; Langergaard 2011). I Danmark er idéen om en innovativ offentlig sektor dog først kommet til i 2005, hvor den optræder i den daværende regerings debatpjece om, hvordan Danmark skal håndtere globaliseringens udfordringer. Under overskriften: "Savnes: Et innovativt loft til hele Danmark", står der, at "også den offentlige sek.tor har brug for at vare innovativ og forny sig" (Regeringen 2005: 34). Fra da af begynder innovation i den offentlig sektor at optræde i forskellige handlingsplaner og strategier, og der iværksættes en række initiativer.

Baggrunden for at innovation kommer på dagsordenen i den offentlige sektor er en oplevelse af, at bestemte udfordringer stiller betydelige krav til nytænkning og forandring i den offentlige sektor for at sikre, at det offentlige udgiftsniveau ikke eksploderer (Forsknings- og Innovationsstyrelsen 2008: 11-12; Sørensen og Torfing 2012: 25). Her kan nævnes demografiske ændringer (Bason 2007; Forsknings- og Innovationsstyrelsen 2008: 11) og stigende krav fra samfundet til god og effektiv service. Dette trækker den offentlige sektor $\mathrm{i}$ en mere efterspørgselsorienteret retning. Ligeledes stiller globaliseringen og målsætningen om at styrke den strukturelle konkurrenceevne krav til en offentlig sektor, som går forrest $\mathrm{i}$ kampen for et kreativt samfund, der kan finansiere fremtidens velfærd (Sørensen og Torfing 2012: 26).

Vi kan forstå ud fra ovennævnte, at innovation er noget, der skal 
løse problemer, selvom det ikke er klart, hvordan det nærmere bestemt skal foregå. At innovation er blevet et fokusområde i den offentlige sektor siger ikke i sig selv så meget om, hvad det nærmere bestemt går ud på. Så lad os se, hvordan innovation defineres.

\section{Innovation og det offentlige}

Det er kendetegnet ved den danske innovationsdagsorden, at man bruger begreber fra den økonomiske innovationsteori til at definere innovation i den offentlige sektor. I 'Strategi for styrket innovation i den offentlige sektor' (2008) præsenteres definitionen:

Innovation er implementeringen af et nyt eller væsentligt forbedret produkt (vare eller tjenesteydelse), proces, markedsføringsmetode eller væsentlig organisatorisk ændring. Innovationer er resultater af bevidste planer og aktiviteter rettet mod en forbedring af virksomhedens produkter, processer, valg af markedsføring eller organisering. Innovationer kan tage udgangspunkt i ny viden og teknologi, men kan også være kombinationer af, eller nye anvendelsesmuligheder for, eksisterende viden og teknologier (Forsknings- og Innovationsstyrelsen 2008:8).

Denne definition, der bygger på Schumpeter, bruges af OECD i innovations-statistikker. Den er oprindeligt udarbejdet med udgangspunkt i private virksomheder, hvilket er helt tydeligt, når man ser, hvilke fornyelser, man tænker som innovation. Det er tydeligt, at vi her har at gøre med overførsel af et begreb om forandring og forbedring fra en privatøkonomisk til en offentlig og politisk kontekst. Ved en gennemgang af litteraturen om innovation i den offentlige sektor vil man også se, at begrebet ikke er løsrevet fra sin kontekst i det virksomhedsøkonomiske teoriunivers og at der er meget få forsøg på at definere et offentligt innovationsbegreb (Langergaard 2011), selvom det retfærdigvis skal siges, at der er et stigende fokus på behovet for et offentligt innovationsbegreb (eksempelvis Jæger 2009; Sørensen og Torfing 2012). Og det er bestemt heller ikke alle innovationsbegreber, der tager afsæt i Schumpeter. Eksempelvis definerer Sørensen og Torfing (2012) innovation som en mere eller mindre intenderet og proaktiv proces, som udvikler, implementerer og spreder nye og kreative idéer, der skaber en kvalitativ for- 
andring i en given kontekst (Sørensen og Torfing, 2012: 29). Ved at fremhæve, at konteksten er væsentlig tages også forbehold for, at innovation kan være noget bestemt i en offentlig kontekst, men der gives ikke noget systematisk bud på, hvordan den demokratiske kontekst spiller en rolle for, hvordan vi i normativ forstand skal forstå offentlig innovation. Der lægges dog op til, at en evaluering af en konkret innovations positive eller negative udfald skal foretages af alle de berørte og relevante samarbejdspartneres opfattelse af resultatet (Sørensen og Torfing 2012: 30). Dette er et væsentligt kriterium for vurderingen af konkrete innovationsaktiviteter, men det siger ikke så meget om, hvordan et begreb om offentlig innovation kan forholde sig til en udvikling af den offentlige sektor i mere generel forstand og som en udvikling, hvor det demokratiske har en fundamental betydning.

Ofte defineres innovation i den offentlige sektor dog med udgangspunkt i Schumpeters innovationstypologi (for eksempel Bason 2007; Koch and Hauknes, 2005, Halvorson et al. 2005; Hartley 2005; Windrum 2008). Der præsenteres forskellige innovationstyper, eksempelvis produktinnovation, serviceinnovation, procesinnovation, organisatorisk innovation, administrativ innovation, politikinnovation, og demokratiinnovation. Her kobles typerne politikinnovation og demokratiinnovation oftest på som 'add-ons' til en mere traditionel innovationstypologi (Langergaard 2012), men det er ikke typer, der er begrebsligt veludviklede på en sådan måde, at der er nogen bud på hvordan eksempelvis demokratiinnovation konkret kan forstås (Bason 2007; Langergaard og Carstensen, 2014). Denne måde at definere innovation fokuserer på genstanden for fornyelse snarere end på rammerne for fornyelsen eller på den værdi, der skabes. Det kan være et skridt på vejen at åbne op for nye områder eller genstande for fornyelse, såsom offentlige services frem for kun kommercielt udbudte services. Men hvis man blot fylder nye typer på, forholder man sig grundlæggende ikke til de forudsætninger og antagelser, som det innovationsbegreb, man bygger videre på, hvilker på. Derfor kan sådanne definitioner betragtes som enten for snævre, upræcise eller som decideret malplacerede i en offentlig kontekst, da de netop som udgangspunkt knytter sig til forandringer, der skaber konkurrencedygtighed på markedet og fører til skabelse af økonomisk, kommerciel værdi frem for demo- 
kratiske, almene anliggender. Som et overordnet forandringsbegreb for den offentlige sektor er det primære problem, at den ikke rummer offentlige og demokratiske dimensioner. Umiddelbart er det derfor yderst vanskeligt at se, hvordan sådan en forståelse af innovation skulle kunne understøtte en udvikling, hvor den offentlige sektor arbejder på at blive bedre til at varetage almene anliggender på en demokratisk legitimeret måde. Jeg er af den overbevisning, at det er utilstrækkeligt som bud på et innovationsbegreb, at man fremhæver, at den pågældende kontekst skal tages i betragtning. Det må indebære et mere substantielt bud på, hvordan det offentlige spiller en rolle for et overordnet forandringsbegreb for sektoren. Jeg mener derved, at man er kommet et stykke ad vejen, men at man må være mere radikal i sit forsøg på at definere et specifikt offentligt innovationsbegreb.

Forsknings- og Innovationsstyrelsens strategi for innovation i den offentlige sektor (2008) understreger, at innovation i den offentlige sektor må skabe værdi på mindst én af fire parametre:

\section{1. Øget effektivitet i offentlige processer og ydelser}

2. Bedre kvalitet i offentlige serviceydelser til virksomheder og borgere

3. Styrket demokrati, legitimitet og retssikkerhed i samfundet

4. Større medarbejdertilfredshed gennem dynamiske og attraktive arbejdspladser der fremmer rekruttering og fastholdelse af medarbejdere

Vi finder andre steder lignende eksempler, hvor innovation i den offentlige sektor skal skabe værdi på flere forskellige bundlinjer (Bason 2007; Carstensen 2010). Dette kan betragtes som et forsøg på at tilpasse begrebet til den offentlige kontekst. Ved at se på disse parametre kommer der fokus også på den værdi, der skabes og ikke blot på, hvad der fornyes. Disse bestræbelser på at tilpasse begreber er et godt udgangspunkt for at diskutere, hvordan vi kan tænke et innovationsbegreb der understøtter det offentliges demokratiske og politiske aspekter. Nummer 1 og nummer 4 vil jeg gå let hen over, da jeg ikke betragter disse innovationsmål som særligt knyttet til det offentlige. Det skal ikke forstås sådan, at jeg ser innovation i 
den offentlige sektor som noget, der er afgrænset fra disse, men jeg betragter ikke en diskussion af disse som det bedste udgangspunkt for at præcisere et offentligt innovationsbegreb. Jeg vil i stedet gå mere i dybden med nummer 2 og 3 . Den værdi eller fornyelse, som offentlig innovation kan skabe, må tænkes ligeså kompleks og politisk bestemt som de almene goder, som den offentlige sektor beskæftiger sig med.

\section{Bedre kvalitet i offentlige serviceydelser til virksomheder og borgere}

Gennem en diskussion af kvalitet i serviceydelser som mål for innovation i den offentlige sektor vil jeg forsøge at udpege noget specifikt for den offentlige sektor. Skal den offentlige sektor være innovativ i den forstand, at den skal levere bedre kvalitet i serviceydelserne? Ja, det skal den umiddelbart, men her er det væsentlig at tydeliggøre det særegne ved netop at højne kvaliteten af de offentlige serviceydelser. Innovation, som har til mål at udvikle, forny eller forbedre services, tænkes i de fleste tilfælde som en form for brugerdreven innovation. Brugerdreven innovation kan forstås på flere forskellige måder, og brugeren kan begrebsliggøres på flere måder, for eksempel som stakeholder (Hartley 2005), forbruger, med-producent (King and Martinelli 2005: 2), borger eller klient.

Det egentlig interessante her er, at brugerne af offentlige services er borgere (og i nogle tilfælde virksomheder). Og ligeledes er det interessante spørgsmål, hvad det vil sige at udvikle kvalitet $\mathrm{i}$ netop offentlige services, når vi betragter den offentlige sektor som beskrevet ovenfor, som politisk institution. Her har de teorier og metoder, som er udviklet med henblik på kommercielle services deres klare begrænsninger. Men vi ser flere eksempler på, at begreber om brugerdreven innovation i den offentlige sektor er inspireret af brugerinddragelse i den private sektor.

Brugerdreven innovation kom for alvor på dagordenen i Danmark med Erhvervs- og Byggestyrelsens 'Program for Brugerdreven Innovation' fra 2007 der med en årlig ramme på 100 mio. kroner støttede projekter i den private og offentlige sektor med fokus på produkter, der imødekom kunders og borgeres behov og ønsker. Her handlede brugerdreven innovation om: 
[...] at udvikle nye produkter eller ydelser på baggrund af en systematisk inddragelse af brugernes behov. Brugerdreven innovation er andet og mere end tilfredshedsundersøgelser og fokusgrupper, hvor brugerne spørges direkte. Fokus i brugerdreven innovation er især på at afdække ikke-erkendte eller fremtidige behov og prioriteringer. (Sekretariatet for Ministerudvalget 2007: 1).

I regeringens kvalitetsreform fra 2007 er brugerdreven innovation defineret som udviklingen af nye produkter og services på grundlag af en systematisk afdxkning af brugernes behov og ønsker (Regeringen 2007: 96). I disse eksempler betragtes borgerne som en bruger med ønsker og behov, som den offentlige sektor skal afdække.

Set fra et demokratisk perspektiv indebærer disse begreber om borgeren som bruger nogle problemer, der hænger sammen med forskellen på offentlige og private services og med forskellen på borgere og kunder. Offentlige services har ikke til formål at møde private, subjektive præferencer hos borgerne, som de services, der leveres via markedet. De har til formål at tilgodese netop de almene og offentlige anliggender, som defineres som politiske i den politiske offentlighed. De anliggender, der menes at gælde alle samfundets borgere, såsom uddannelse, sundhed, sikkerhed mv. Selvom disse udmønter sig i services, der leveres til samfundets individer har de ikke en privat, subjektiv og individuel karakter, som private services har. De har en politisk og almen dimension. Dette ses ligeledes ved, at borgerne står i forhold til den offentlige sektor gennem forskellige rettigheder (Marshall 2003), hvor man ofte tænker på de sociale rettigheder, når det handler om offentlige serviceydelser. Ved at fremstille borgeren som en stakeholder hvis behov skal mødes, får vi en idé af personen som først og fremmest bærer af interesser (Pedersen 2011: 191), og derved bliver den offentliges sektors opgave en helt anden. Behov og interesser, som kan afdækkes af den offentlige sektors medarbejdere i brugerdrevne innovationsprocesser er før-politiske, private og subjektive, og derved langt fra de almene anliggender, som den politiske offentlighed retter sig mod. Selvom nogle services rettes mod den enkelte borger, kan forbedret kvalitet stadig kun forstås i forhold til almene kriterier såsom retfærdighed, eller som noget der understøtter borgernes gode liv. Elevens uddannelse i skolen 
handler for eksempel ikke nødvendigvis blot om den enkeltes færdigheder, men ligeledes om skolen som et dannelsesfællesskab for borgerne. Ligeledes er behandlingen af den enkelte borgers skattesag bundet op på en retssikkerhed, der betyder at alle borgeres skattesager behandles efter de samme principper (se også Langergaard og Carstensen 2014). Ved at overse disse aspekter sker en afpolitisering, som ligeledes frakobler den offentlige sektor demokratiske input. Vi går fra en borger, der måske nok på sin vis kan ses som en klient i mødet med det offentlige (se eks. Fraser 1985; Habermas 1996), men som ikke desto er berettiget til offentlige services som borger med rettigheder, til en bruger i mere generisk og apolitisk forstand. Borgeren er som klient måske nok privatperson i én forstand, men hvis borgeren som bruger skal deltage i udvikling eller design af offentlige services må denne tage en rolle, der ligeledes rummer offentlige aspekter. Eksempelvis fra et deliberativt perspektiv indgå $i$ en diskurs om udviklingen af disse services, hvor det bliver klart, at det er borgernes fælles samfundsmæssige institutioner og deres opgaveløsninger, der er på spil.

Så når vi skal forstå innovation som forbedring af kvaliteten af offentlige services kan man skelne mellem forskellige tilgange til borgerinddragelse: På den ene side de ovenfor kritiserede tilgange, der er inspireret af privat serviceinnovation og som har et individualiseret perspektiv på borgeren, som én der skal have opfyldt subjektive private behov; på den anden side deliberative tilgange til deltagelse, hvor personer gennem diskussion når en konsensus om løsninger på fælles anliggender, eller afklarer normer og etiske spørgsmål, der har med de offentlige services at gøre. Der findes en lang tradition for demokratisk brugerinddragelse inden for eksempelvis socialt arbejde (Beresford 2002: 96; McLaughlin 2009: 3), for offentlige høringer, og decentrale bruger-drevne bestyrelser $\mathrm{i}$ offentlige institutioner, såsom børnehaver, skoler, mv. Det vil derfor være muligt at udvikle den offentlige sektor gennem borgerdeltagelse, der er langt mere demokratisk i sit tilsnit, end de oven for nævnte eksempler på brugerdreven innovation. 


\section{Styrket demokrati, legitimitet og retssikkerhed}

Man møder sjældent begreber som legitimitet og retssikkerhed i innovations-litteraturen, og de få steder de nævnes, gives der ingen mere præcise svar på, hvordan vi skal forstå dem. Christian Bason nævner, at der er en særlig udfordring ved at definere denne type innovation (som han kalder demokrati-innovation), idet der ikke er konsensus om, hvordan man måler styrket demokrati (Bason 2007: 57). Måske er det forklaringen på, at stort set ingen forsøger at definere det nærmere. Det kan også forklares med, at innovationsforskningen tilstræber at være politisk og normativt neutral og værdifri og derfor ikke beskæftiger sig med demokrati og rettigheder. Noget andet interessant er, at disse værdier rammer ned i de modsatrettede krav til den offentlige sektor til på den ene side at være innovativ, nyskabende og dynamisk og på den anden side at være stabil, forudsigelig og opretholde procedurer, der sikrer en konsistent sagsbehandling. Forskerne Eva Sørensen og Jacob Torfing, som har medvirket til at sætte offentlig innovation på den danske dagsorden, nævner da også, at der er nogle bestemte krav til retssikkerhed, offentlighed og kontrol i den offentlige sektor og at den offentlige sektor er forankret i en række værdier som stabilitet, åbenhed og ligebehandling, "som i nogle tilfælde hindrer innovation" (Sørensen og Torfing 2012: 27).

Spørgsmålet er, om det er en rimelig måde at anskue det på, at "værdier om ligebehandling og åbenhed" hindrer innovation, eller om det snarere kan betragtes som en ureflekteret overførsel af indsigter fra innovationsteorien. Vil nye tilgange til styrkelse af ligebehandling og åbenhed ikke i sig selv kunne tænkes som innovation? I innovationsteorien er en af de mest udbredt accepterede sandheder, at innovation står i modsætning til bureaukrati (eksempelvis Burns and Stalker 1994), hvilket for fortalerne for New Public Management får den implikation, at alt der er forbundet med den offentlige sektor betragtes som rigidt, ineffektivt og dysfunktionelt (Osborne and Gaebler 1992). Bureaukratiet er meget udskældt, men kan ikke desto mindre betragtes som en organisationsform, hvor bestemte strukturer og etiske værdier sikrer ligebehandling, retssikkerhed, stabilitet og upartisk sagsbehandling (se eks. du Gay 1994). Og disse er væsentlige for at den offentlige sektor kan sikre legitimitet 
og retssikkerhed. Hvis vi ser bort fra de eksisterende markedsorienterede begreber om innovation og i stedet tænker på innovation som en form for udvikling, der skal styrke den offentlige sektor i sit virke som netop offentlig sektor, vil nye og forbedrede bureaukratiske procedurer også kunne betragtes som innovation. Det viser, at vi er nødt til at tænke ud over de gængse definitioner og indsigter, hvis vi skal kunne overføre begrebet til den offentlige sektor.

\section{Konklusion: Der er brug for et offentligt innovationsbegreb}

På spørgsmålet om den offentlige sektor skal være innovativ, er svaret, at det kommer an på, hvordan vi definerer innovation. De begreber, der overtages fra den traditionelle innovationsteori handler om kommercielle innovationer og udvikling af produkter og services til et marked. Hvis man blot overfører disse begreber til den offentlige sektor bliver det problematisk fra et demokratisk perspektiv, da de definerer innovation, som noget, der gør en økonomisk forskel og som udvikling af services, markeder eller produkter, hvilket ikke understøtter den offentlige sektors demokratiske forpligtelser. Vi har set, at der kun i meget begrænset omfang er gjort seriøse forsøg på gentænke innovationsbegrebet på en måde, som tydeliggør hvordan vi skal forstå de demokratiske aspekter ved den offentlige sektor i forbindelse med begrebet. Anken i artiklen går derved på, at nok er der en opmærksomhed omkring at den offentlige sektor opererer under nogle andre betingelser end den private, men der synes ikke for alvor at være anledning til mere radikal nytænkning af innovationsbegrebet - snarere synes svaret at være mindre justeringer eller tilføjelser.

Hvis vi tager udgangspunkt $\mathrm{i}$ innovation i mere bred (og ikke nødvendigvis økonomisk) forstand som en form for fornyelse eller fremskridt, kan det godt defineres på en måde, som er bedre tilpasset den offentlige sektors rolle og demokratiske dimensioner. Her bliver det jo netop spørgsmålet, hvad det vil sige at udvikle på den offentlige sektor, og om begrebet skal være et mere overordnet udviklingsbegreb, som det er inden for den økonomiske innovationsteori. For at det kan være et begreb, der adskiller sig fra blot forandring, må det kvalificeres yderligere og her er en endnu mere vidtrækkende udvikling af begrebet nødvendig, som erstatter det økonomiske, markedsorienterede 
grundlag i innovationsteorien med et demokratiteoretisk grundlag. Den ikke-økonomiske innovationsteori arbejder med et begreb om innovation som social forandring og somme tider som noget, der skaber social værdi, men vi kan blive mere præcise end det ved at inddrage demokratiteoretiske begreber og idéer.

Gennem en diskussion af nogle af de forskellige parametre, som innovation i den offentlige sektor siges at skabe værdi på, kom jeg nærmere på, hvordan man kan tænke offentlig innovation. Jeg satte især fokus på øget kvalitet i serviceydelser som mål for offentlig innovation, fordi det her er væsentligt at være præcis omkring hvad kvalitet i offentlige services vil sige. Ved at præcisere dette kommer man tættere på at forstå behovet for et offentlige innovationsbegreb. Det må indebære, at man tager med i betragtning, at offentlige services handler om almene anliggender, der er politiske og som legitimeres som offentlige og almene gennem den offentlige menings- og viljesdannelse i den offentlige sfære. De kan ikke reduceres til før-politiske og private interesser eller behov, uden at der er risiko for tab af den demokratiske forankring. Det betyder, at deliberative deltagelsesmetoder er mere passende for udvikling af offentlige services end markedsinspirerede metoder til brugerdreven innovation. Pointen er her ikke at afgrænse den politisk-demokratiske samtale til udelukkende at handle om bestemte aspekter ved den offentlige sektor og derved afgrænse innovation til kun at handle om serviceudvikling eller retssikkerhed. Principielt må der være rum for, at de anliggender, der gøres til genstand for offentlig deliberation, vælges af deltagerne selv. I den forstand knytter definitionen af det offentlige an til en procedural sondring mellem privat of offentlig, altså således at det ikke på forhånd er givet hvilke anliggender, der er private og offentlige henholdsvis. Det afgøres gennem den offentlige samtale. Borgerne kan således inddrages $i$ overvejelser om effektivitet ligesom man vil kunne lave innovative tiltag med henblik på at forbedre arbejdsforholdene for offentligt ansatte, eksempelvis under inddragelse af medarbejderne selv.

Der er i artiklen blevet argumenteret for, at vi må gøre op med etablerede indsigter fra innovationsteorien, at stabilitet og bureaukratiske procedurer per se er i modsætning til innovation. Det er væsentligt for den offentlige sektors legitimitet og for, at den kan garantere retfærdighed i sagsbehandlingen, at den udfører sin prak- 
sis i overensstemmelse med faste procedurer og regler. Disse regler og procedurer understøttes netop af bureaukratiet. Bureaukrati kan derfor også understøtte innovation i legitimitet og retssikkerhed, hvis man finder nye måder at sikre disse.

Som udgangspunkt er spørgsmålet, hvordan de udviklinger, vi betegner som innovation, undgår at blive frakoblet det politiske. Hvis innovation reduceres til udelukkende tekniske elementer/løsninger, og derved erstatter politiske valg i forhold til fordeling og rettigheder, ender det som ansvarsfralæggelse fra politisk side. Hvis løsningen for fremtidens offentlige sektor udelukkende bliver et administrativt innovationsærinde, risikerer vi et demokratisk tab. Så vil innovation som løsning på globaliseringens, demografiens og den krævende befolknings udfordringer ligge inden for idéen om "nødvendighedens politik", der sætter en diskurs om, at der er samfundsmæssige problemer til hvilke, der findes bestemte løsninger, som man er "nødt til" at gennemføre for at komme problemet til livs. Den nedtoner, at der i politik altid er alternativer, og at det handler om på demokratisk vis at drøfte og argumentere for disse forskellige alternativer (Steen 2013). Innovation i den offentlige sektor kan indskrive sig i denne form for politik, der reelt set er en afpolitisering og en frakobling af de politiske institutioner fra den politiske offentlighed, hvis ikke vi gentænker begrebet.

Et offentligt innovationsbegreb må derfor eksplicit forholde sig til demokratiske dimensioner ved den offentlige sektor og til begreber som demokrati, rettigheder og retssikkerhed. Det betyder, at en offentlig innovationsteori også må bevæge sig ud over at være værdifri socialvidenskab og i stedet må forholde sig til disse begreber som normative, politisk filosofiske begreber. Det betyder, at man må leve med den flertydighed, der er i disse begreber, og at man indlader sig på at ville debattere og argumentere for, hvordan vi nærmere bestemt skal forstå en udvikling af de offentlige institutioner, der er mere demokratisk og som styrker den offentlige sektors evne til at beskæftige sig med almene, politiske anliggender. 


\section{Litteratur}

Altschuler, Alan and Mark Zegans (1990): "Innovation and Creativity: Comparisons between Public Management and Private Enterprise”, i Cities, February 1990, vol. 7, nr. 1, s. 16-24.

Arendt, Hannah (2007): Menneskets vilkår. København: Gyldendal.

Austin, James, Howard Stevenson and Jane Wei-Skillern (2006): "Social and Commercial Entrepreneurship: Same, Different or Both?", i Entrepreneurship Theory and Practice, January, 2006, s. 1-22.

Bason, Christian (2007): Velfardsinnovation - ledelse af nytankning $i$ den offentlige sektor. København: Børsens Forlag.

Becheikh, Nizar, Norrin Halilem, Jalila Jbilou, Elaine Mosconi, Hajer Hammami and Réjean Landry (2007): "Conceptualization and Determinants of Innovation in the Public Sector: A Systematic Review", Conference paper presented at the $14^{\text {th }}$ Reser International Conference on Service Competitiveness and Cohesion, September 2007.

Benhabib, Seyla (1992): "Models of Public Space: Hannah Arendt, the Liberal Tradition, and Jürgen Habermas", i Graig Calhoun (red.), Habermas and the Public Sphere. Cambridge and London: MIT Press, s. 71-98.

Beresford, Peter (2002), "User involvement in Research and Evaluation: Liberation or Regulation?" i Social Policy and Society, vol. 1, nr. 2, s. 95 105.

Borins, Sandford (2006): The Challenge of Innovation in Government. Published by IBM Center for The Business of Government.

Burns, Tom and George M. Stalker (1994): The Management of Innovation. Oxford: Oxford University Press.

Carstensen, Helle Vibeke (2010): 'Innokrati - ledelse som understøtter innovation". Dansk Ledelsesakademis konference, december 2010. http:// www.det-danske-ledelsesakademi.dk/2010/papers_2010/Paper_Carstensen $\% 20$ inkl $\% 20$ figurer-rev.pdf

Christopher, Gail C. (2003): "Innovative government practice: considerations for policy analysts and practitioners" i Journal of Policy Analysis and Management, vol. 22, nr. 4, s. 683-688.

Dees, J. Gregory (1998): “The Meaning of Social Entrepreneurship", i The Kaufmann Center for Entrepreneurial Leadership. http://www.caseatduke.org/documents/dees_sedef.pdf

Drejer, Ina (2004): "Identifying innovation in surveys of services: a Schumpeterian perspective", i Research Policy 33, s. 551-562.

Ejersbo, Niels og Carsten Greve (2005): Moderniseringen af den offentlige sektor. København: Børsens Forlag A/S.

Eriksen, Erik Oddvar (1999): Kommunikativ Ledelse - om styring av offentlige organisasjoner, fagbokforlaget. Bergen: Vigmostad \& Bjørke AS. 
Fagerberg, Jan (2005): "Innovation - A Guide to the Literature" in Jan Fagerberg, David C. Mowery and Richard R. Nelsen (red.), The Oxford Handbook of Innovation. Oxford: Oxford University Press, s. 1-26.

Forsknings- og innovationsstyrelsen (2008): Strategi for styrket innovation i den offentlige sektor. http://ufm.dk/publikationer/2008/filer-2008/strategi-forstyrket-innovation-i-den-offentlige-sektor.pdf

Fraser, Nancy (1985): "What's Critical about Critical Theory? The Case of Habermas and Gender", i New German Critique, (No. 35, Special Issue on Jürgen Habermas), s. 97-131.

Fraser, Nancy (1992): "Rethinking the Public Sphere: A Contribution to the Critique of Actually Existing Democracy”, i Graig Calhoun (red.), Habermas and the Public Sphere. Cambridge and London: MIT Press, s. 109-142.

Gay, Paul du (1994): "Making up Managers: Bureaucracy, Enterprise and the Liberal Art of Separation", i The British Journal of Sociology, vol. 45, nr. 4, s. 655-674.

Geuss, Raymond (2001): Public Goods, Private Goods. Princeton and Oxford: Princeton University Press.

Godin, Benoît (2008): "Innovation - The History of a Category". Project on the Intellectual History of Innovation, Working Paper No. 1. http://www.csiic.ca/ PDF/IntellectualNo1.pdf

Godin, Benoît (2012): "Social Innovation: Utopias of Innovation from c. 1830 to the Present". Project on the Intellectual History of Innovation, Working Paper No. 11. http://www.csiic.ca/PDF/SocialInnovation_2012.pdf

Golden, Olivia (1990): "Innovation in public sector human services programs: The implications of innovation by "groping along", i Journal of Policy Analysis and Management, vol. 9, nr. 2, s. $219-248$.

Grady, Dennis O. (1992): "Promoting innovations in The Public Sector", i Public Productivity \& Management Review, vol. 16, nr. 2, s. 157-171.

Habermas, Jürgen (1996): Between Facts and Norms - Contributions to a Discourse Theory of Law and Democracy. Cambridge: Polity Press.

Halvorson, Thomas, Johan Hauknes, Ian Miles \& Rannveig Røste (2005): On the Differences Between public and private sector innovation. Publin Report No. D9, NIFU STEP. http://survey.nifu.no/step/publin/reports/d9differences.pdf

Hartley, Jean (2005): "Innovation in Governance and Public Services: Past and Present", i Public Money and Management, January 2005, s. 27-34.

Jæger, Birgit (2009): "User-driven innovation in the public service delivery". Paper presented at the 2009 annual conference of EGPA. https://www.scss.tcd.ie/ disciplines/information_systems/egpa/docs/2009/Jaeger.pdf

Klausen, Søren Harnow (2012): “Hvad er innovation?”, i Michael Paulsen \& Søren Harnow Klausen (red.), Innovation og laring: Filosofiske og kritiske perspektiver. Aalborg: Aalborg Universitetsforlag, s. 235-260. 
King, Cheryl Simrell and Alicia Seegers Martinelly (2005): "Introduction - Innovations in Citizen Engagement and Empowerment: Beyond Boundaries", i The Innovation Journal: The Public Sector Innovation Journal, vol. 10, nr. 1, s. $1-8$.

Koch, Per \& Johan Hauknes (2005): On Innovation in the Public Sector. Public Report no. D20, NIFU STEP. http://survey.nifu.no/step/publin/reports/ d20-innovation.pdf

Langergaard, Luise Li (2011): Innovating the publicness of the public sector - a critical philosophical discussion of public sector innovation. Ph.d-afhandling. Roskilde Universitetsforlag.

Langergaard, Luise Li (2012): "Innovation som en styrkelse af det offentlige ved den offentlige sektor?”, i Søren Harnow Klausen \& Michael Paulsen (red.), Innovation og laring $i$ kritisk og filosofisk perspektiv. Aalborg: Aalborg Universitetsforlag, s. 119-140.

Langergaard, Luise Li and Helle Vibeke Carstensen (2014): "Democracy innovation in public authorities. Learning from the Danish Ministry of Taxation.", i The Innovation Journal - Public Sector Innovation Journal, Volume 19(1) 2014, Article 4.

Libbey, Meryl G. (1994): "Reengineering Public Innovation.”, i Public Productivity \& Management Review, vol. 18, nr. 2, s. 163-175.

Lundvall, Bengt-Åke (2007): "Innovation System research and Policy: Where it came from and where it might go". Globelics Working Paper Series, No. 2007-01. https://smartech.gatech.edu/jspui/bitstream/1853/43444/1/ GA2008\%20Lecture\%201.pdf

Marshall, Thomas Humphrey (2003): Medborgerskab og social klasse. København: Hans Reitzels Forlag.

McLaughlin, Hugh (2009): 'What is a Name: 'Client', 'Patient', 'Customer', 'Consumer', 'Expert by Experience', 'Service User' - What's Next?”, i The British Journal of Social Work, vol. 39, s. 1101-1117.

Osborne, David and Ted Gaebler (1992): Reinventing Government - How the Entrepreneurial Spirit is Transforming the Public Sector. Addison-Wesley Publishing Company, Inc.

Paulsen, Michael (2012): "Innovationsbegrebets dialektik i en uddannelseskontekst”, i Michael Paulsen og Søren Harnow Klausen (red.), Innovation og laring - filosofiske og kritiske perspektiver. Aalborg: Aalborg Universitetsforlag.

Pedersen, Ove Kaj (2011): Konkurrencestaten, København: Hans Reitzels Forlag. Regeringen (2005): Danmark og globaliseringen - debatpjece om globaliseringens udfordringer for Danmark. Albertslund: Schultz Distribution.

Regeringen (2007): Bedre velfærd og større arbejdsglæde - Regeringens strategi for bedre kvalitet i den offentlige service. Albertslund: Schultz Distribution. 
Robertson, Thomas S. (1967): "The Process of Innovation and the Diffusion of Innovation", i Journal of Marketing, vol. 31, nr. 1, s. 14-19.

Rogers, Everett M. (1995): Diffusion of Innovations - Forth Edition. New York: The Free Press.

RUC (2013): CLIPS - Collaborative Innovation in the Public Sector. http:/ /www. ruc.dk/clips, siden besøgt 31.03.2014.

Sanger, Mary Bryna and Martin A. Levin (1992): "Using Old Stuff in New Ways: Innovation as a Case of Evolutionary Tinkering", i Journal of Policy Analysis and Management, vol. 11, nr. 1, s. 88-115.

Sekretariatet for ministerudvalget (2007): Fakta om program for brugerdreven innovation. Kvalitet i den offentlige sektor. http://www.stm.dk/multimedia/ Faktabilag_brugerdreven_innovation.pdf

Steen, Jens Jonathan (2013): 'Hvad er 'nødvendig' politik", http:/ /www.cevea. $\mathrm{dk} /$ debatindlaeg/er-noedvendig-politik, siden besøgt 19.03.2013.

Sørensen, Eva og Jacob Torfing (2012): "Samarbejdsdreven innovation i den offentlige sektor”, i Eva Sørensen og Jacob Torfing (red.), Samarbejdsdrevet innovation - $i$ den offentlige sektor, København: Jurist- og økonomiforbundets Forlag, s. $19-37$.

Tidd, Joe, John Bessant and Keith Pavitt (2001): Managing Innovation - Integrating Technological, Market and Organizational Change, West Sussex: Wiley and Sons.

Windrum, Paul (2008): "Innovation and entrepreneurship in public services", i Paul Windrum \& Per Koch (red.), Innovation in Public Sector Services - Entrepreneurship, Creativity and Management, Cheltenham: Edward Elgar, s. 3-20. 